\title{
Honokiol inhibits migration of renal cell carcinoma through activation of RhoA/ROCK/MLC signaling pathway
}

\author{
SHUJIE CHENG ${ }^{1,5}$, VICTOR CASTILLO ${ }^{1}$, MATT WELTY $^{1}$, ISAAC ELIAZ ${ }^{2}$ and DANIEL SLIVA ${ }^{1,3,4}$ \\ ${ }^{1}$ Cancer Research Laboratory, Methodist Research Institute, Indiana University Health, Indianapolis, IN; \\ ${ }^{2}$ Amitabha Medical Clinic and Healing Center, Santa Rosa, CA; ${ }^{3}$ Department of Medicine, School of Medicine, \\ Indiana University; ${ }^{4}$ DSTest Laboratories, Purdue Research Park, Indianapolis, IN, USA
}

Received June 15, 2016; Accepted August 2, 2016

DOI: 10.3892/ijo.2016.3663

\begin{abstract}
Honokiol, a biologically active compound isolated from Magnolia bark, has been shown to possess promising anticancer effect through induction of apoptosis. However, there is a relative lack of information regarding its anti-metastatic activity. Renal cell carcinoma (RCC) is the most common malignancy of the adult kidney and is known for high risk of metastasis. Clinically, therapeutic methods for metastatic RCC cases are limited and efforts to exploit new treatments are still ongoing. The results of our current investigation first revealed that honokiol suppressed the proliferation of different human RCCs without affecting cell viability. In addition, honokiol inhibited migration of highly metastatic RCC 786-0 cells and stimulated the activity of small GTPase, RhoA. Furthermore, phosphorylated myosin light chain (MLC) and excessive formation of actin stress fibers were identified in 786-0 cells treated with honokiol. Interestingly, the pharmacological Rho-associated protein kinase (ROCK) inhibitor Y-27632 attenuated contraction of actin stress fibers induced by honokiol and abrogated honokiol-mediated inhibition of cell migration. Together these important findings suggest that honokiol suppresses the migration of highly metastatic RCC through activation of RhoA/ROCK/MLC signaling and warrants attention in the treatment of RCC metastasis as a novel therapeutic approach.
\end{abstract}

\section{Introduction}

Magnolia bark is obtained from Magnolia officinalis or other species of the Magnoliaceae, which has long been used in

Correspondence to: Dr Daniel Sliva, DSTest Laboratories, Purdue Research Park, 5225 Exploration Drive, Indianapolis, IN 46241, USA

E-mail: dsliva@dstest-lab.com

Present address: ${ }^{5}$ Department of Food Quality and Safety, School of Engineering, China Pharmaceutical University, Nanjing, Jiangsu 210009, P.R. China

Key words: honokiol, renal cell carcinoma, migration, RhoA traditional Chinese and Japanese medicines for treatment of anxiety, depression and allergic disease (1). Growing experimental evidence suggests that individual biologically active compounds isolated from Magnolia bark, such as honokiol, magnolol and obovatol, have anticancer effects against various cancer types in vitro and in vivo (1-3). Most of their promising anticancer effects are the induction of apoptosis through multiple signaling (4-7), however, there is a relative lack of information regarding their anti-metastatic activity, which is considered responsible for $>90 \%$ of cancer-related deaths (8-11).

Renal cell carcinoma (RCC) is the most common malignancy of the adult kidney and is known to have high risk of metastasis. Clinically, therapeutic methods for metastatic RCC cases are limited and efforts to exploit new treatments are still ongoing (12). RhoA, one of the most extensively characterized members of the Rho family small GTPases, shuttles between inactive and active GTP-bound states (13). In post-translational level, the phosphorylation of RhoA at site Ser188 negatively regulates its activity (14). Activated RhoA interacts with its major downstream effector Rho-associated protein kinase (ROCK) that induces the contraction of actin fibers by directly phosphorylating the myosin light chain (MLC) and indirectly inactivate MLC phosphatase (15). A previous study demonstrated that excessive formation of actin stress fibers associated with inhibited migration of RCC in vitro (16). In addition, $\mathrm{Pu}$ et al showed the downregulated expression of RhoA in human conventional RCC tissues in vivo (17), indicating that RhoA/ROCK/MLC signaling pathway might be a suitable target for the metastatic RCC treatment.

Our results indicated that honokiol suppressed invasion and colony formation of RCC by targeting KISS1/KISS1R signaling (18). In this study, we first demonstrate that honokiol suppresses proliferation of human RCC A-498 and 786-0 cells without affecting cell viability. In addition, honokiol inhibits migration of highly metastatic RCC 786-0 $(19,20)$ and stimulates RhoA activity. Furthermore, phosphorylated MLC and excessive formation of actin stress fibers were identified in 786-0 cells treated with honokiol. Interestingly, the pharmacological ROCK inhibitor Y-27632 attenuated contraction of actin stress fibers induced by honokiol and abrogated honokiol-mediated inhibition of cell migration. Together 
these important findings suggest that honokiol suppresses the migration of RCC through activation of RhoA/ROCK/MLC signaling and warrants attention in the treatment of RCC metastasis as a novel therapeutic approach.

\section{Materials and methods}

Cell culture and reagents. Human RCC 786-0 cells were obtained from ATCC (Manassas, VA, USA) and maintained in RPMI-1640 medium containing penicillin $(50 \mathrm{U} / \mathrm{ml})$, streptomycin $(50 \mathrm{U} / \mathrm{ml})$ and $10 \%$ FBS according to the ATCC procedures. Media came from ATCC. Supplements and FBS were obtained from Gibco (Grand Island, NY, USA). Honokiol 98\% (HonoPure ${ }^{\circledR}$ ) was provided by EcoNugenics, Inc. (Santa Rosa, CA, USA) and dissolved in DMSO at a concentration of $80 \mathrm{mM}$ then stored at $-20^{\circ} \mathrm{C}$. Rho-kinase inhibitor Y-27632 was purchased from Calbiochem (Darmstadt, Germany). Rhodamine phalloidin was purchased from Molecular Probes (Grand Island, NY, USA). Methanol-free formaldehyde solution $16 \%$ was purchased from Thermo Fisher Scientific, Inc. (Waltham, MA, USA). DMSO and other reagents were purchased from Sigma (St. Louis, MO, USA). Anti-RhoA, anti-phospho-RhoA and anti- $\beta$-actin antibodies were obtained from Santa Cruz Biotechnology, Inc. (Santa Cruz, CA, USA). Anti-MLC2 and anti-phospho-MLC2 antibodies were obtained from Cell Signaling Technology, Inc. (Beverly, MA, USA).

Cell proliferation and viability assays. Human RCC A-498 and 786-0 cells were treated with indicated concentrations of honokiol for $24 \mathrm{~h}$ and cell proliferation was determined as described (21). Cell viability was determined after incubation with honokiol for $24 \mathrm{~h}$ by staining with trypan blue as described (22). Data are the mean \pm SD from three independent experiments.

Cell migration assay. Cell migration of 786-0 cells treated with honokiol $(0-40 \mu \mathrm{M})$ or honokiol $(20 \mu \mathrm{M})+\mathrm{Y}-27632$ $(10 \mu \mathrm{M})$ or $\mathrm{Y}-27632(10 \mu \mathrm{M})$ was performed in Transwell chambers according to established method (23). Briefly, 786-0 cells $\left(0.2 \times 10^{6}\right)$ suspended in serum-free medium were added to the upper chamber of an insert, and the insert was placed in a 24-well plate containing medium with $10 \%$ FBS. Migration assays were carried out for $3 \mathrm{~h}$. Data points represent the mean \pm SD of three individual filters within one representative experiment repeated at least twice.

Rho activation assay. The Rho Activation Assay Kit (EMD Millipore, Billerica, MA, USA) was used to determine whether honokiol could modulate RhoA activity in 786-0 cells according to the manufacturer's instructions. In brief, cells were exposed to vehicle or honokiol $(20 \mu \mathrm{M})$ for $30 \mathrm{~min}$, rinsed in ice-cold TBS and lysed in the lysis buffer provided. For Rho pull-down assay, cell lysates were incubated with glutathione-agarose beads bounding to a GST-tagged Rho binding domain of Rhotekin. The precipitated GTP-bound forms of proteins were analyzed by western blot analysis with antibody specific for RhoA. Activated RhoA was normalized to the total RhoA. 786-0 cell extract loaded with GTP $\gamma \mathrm{S}$ was used as a positive control.
Western blot analysis. 786-0 cells were treated with vehicle or honokiol $(20 \mu \mathrm{M})$ for 30,60 or $120 \mathrm{~min}$, respectively. Protein extracts isolated from cells were prepared and western blot analysis with anti-phospho-RhoA, anti-RhoA, anti-phospho-MLC2, anti-MLC2 or anti- $\beta$-actin antibodies was performed as previously described (21). Western blots were quantified with HP-Scanjet 550c and analyzed by UN-SCAN-IT software (Silk Scientific, Inc., Orem, UT, USA).

Visualization of actin stress fibers. $786-0$ cells $\left(6.0 \times 10^{4}\right)$ were plated on the Millicell EZ Slide 4-well glass slide (EMD Millipore, Darmstadt, Germany) and incubated for $24 \mathrm{~h}$. After exposure to honokiol $(20 \mu \mathrm{M})$ or honokiol $(20 \mu \mathrm{M})+\mathrm{Y}-27632$ $(10 \mu \mathrm{M})$ or $\mathrm{Y}-27632(10 \mu \mathrm{M})$ for $1 \mathrm{~h}$, cells were washed in PBS and fixed with $4 \%$ formaldehyde for $15 \mathrm{~min}$. The cells were then permeabilized with PBS containing $0.1 \%$ Triton X-100 for $5 \mathrm{~min}$ and stained with rhodamine phalloidin for $20 \mathrm{~min}$. Nucleus was stained with DAPI for 2 min and further washed with PBS. Detection of actin stress fibers was achieved using an inverted microscope (Leica DMR type 020-525-024 fluorescence microscope; Leica Microsystems $\mathrm{GmbH}$, Wetzlar, Germany) and a confocal microscope (Bio-Rad Radiance 2100 laser scanning system; Bio-Rad, Hercules, CA, USA).

Statistical analysis. All statistical analysis was performed using SigmaPlot 11.2.0 (Systat Software, Inc., San Jose, CA, USA). Data are presented as the mean \pm SD. Statistical comparisons were carried out using ANOVA with the significance level adjusted using the repeated t-tests with Bonferroni correction. $\mathrm{P}<0.05$ was considered to be significant.

\section{Results}

Effect of honokiol on the proliferation and viability of RCC. As honokiol exhibits anticancer effects in different cancer types $(6,24-28)$, its effect on the growth of human RCC was evaluated in this study. A-498 and 786-0 cells were treated with honokiol $(0-80 \mu \mathrm{M})$ for $24 \mathrm{~h}$ and proliferation was determined as described in 'Materials and methods'. We found that honokiol suppressed the proliferation of A-498 $\left(\mathrm{IC}_{50}, 37.17 \mu \mathrm{M}\right)$ and 786-0 cells ( $\left.\mathrm{IC}_{50}, 51.28 \mu \mathrm{M}\right)$ dose-dependently (Fig. 1). Moreover, honokiol does not affect the viability of A-498 and 786- 0 cells after treatment of $24 \mathrm{~h}$ (Fig. 1), suggesting cytostatic effect of honokiol on human RCC.

Honokiol inhibits migration of 786-0 cells. Comparing with A-498, the 786-0 cells exhibit higher expression of LIM and SH3 protein 1 (LASP-1), which correlated with aggressive phenotype and poor prognosis in RCC (20). Thus, the more aggressive cell line 786-0 was selected to investigate whether honokiol inhibits cell migration under the incubation time $(3 \mathrm{~h})$ and concentrations $(0-40 \mu \mathrm{M})$ that do not affect viability of 786-0 cells. As shown in Fig. 2, honokiol significantly inhibits cell migration in a dose-dependent manner. Taken together, our data indicate that honokiol not only inhibits proliferation of human RCC but also suppresses migration, an initial important step in cancer metastasis (29).

Honokiol-mediated activation of RhoA/ROCK/MLC signaling in 786-0 cells. To investigate the effect of honokiol and its 

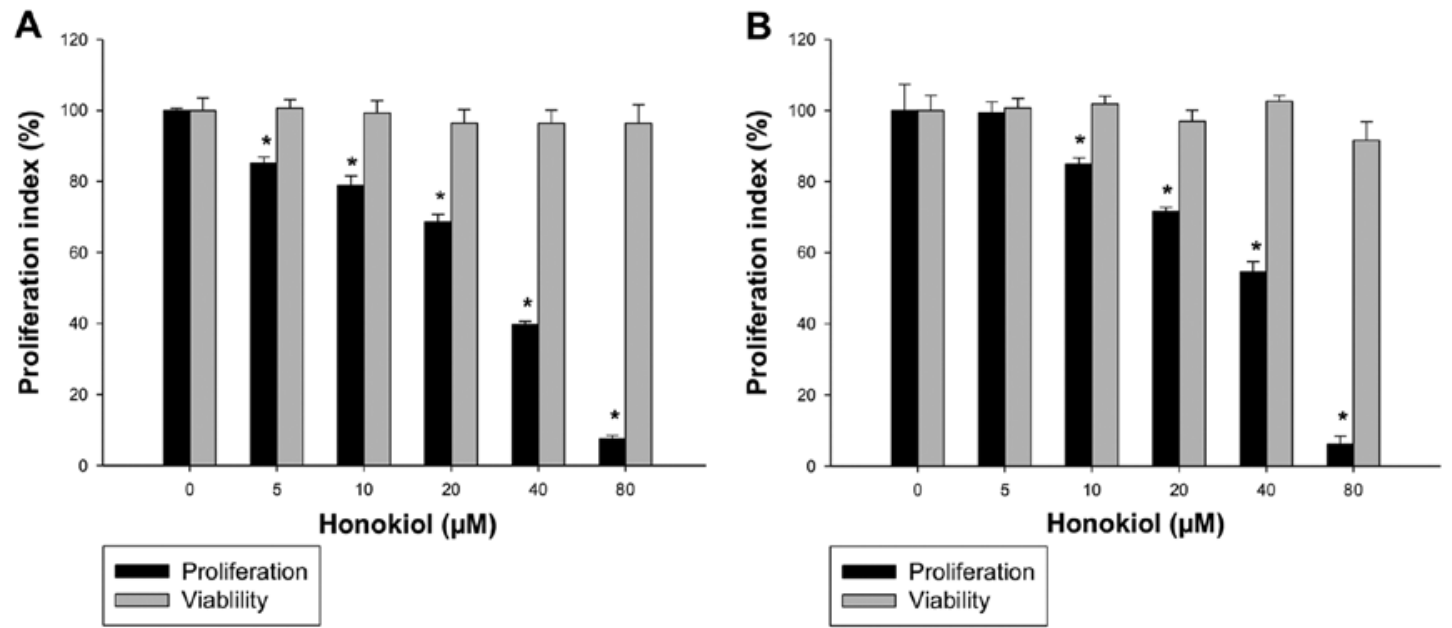

Figure 1. Effects of honokiol on the proliferation and viability of different RCCs. (A) A-498 and (B) 786-0 cells were treated with honokiol (0-80 $\mu \mathrm{M})$ for $24 \mathrm{~h}$. Cell proliferation and viability were determined as described in 'Materials and methods'. Each bar represents the mean \pm SD of three experiments. Similar results were obtained in three independent experiments. Statistical analysis was carried out by ANOVA. "P $<0.05$. RCCs, renal cell carcinomas.

A

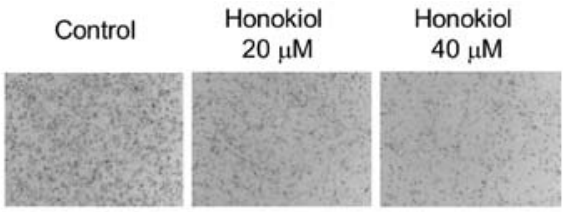

B

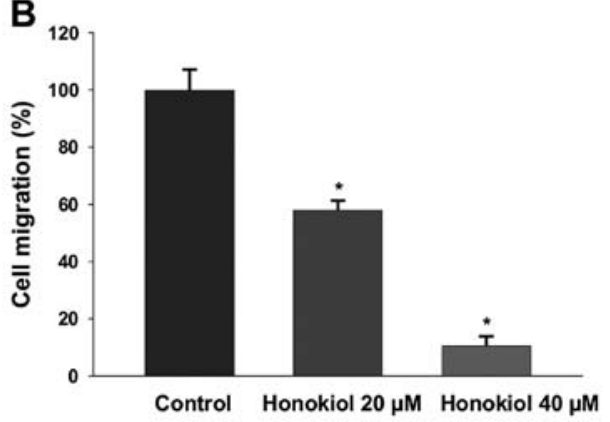

Figure 2. Effect of honokiol on the migration of highly metastatic RCC 786-0. 786- 0 cells were treated with honokiol $(0-40 \mu \mathrm{M})$ and cell migration in Transwell chambers was determined as described in 'Materials and methods'. (A) Representative images of the cell migration are shown. (B) Each bar in the histogram represents the mean \pm SD of one representative experiment repeated at least twice. Statistical analysis was carried out by ANOVA. " $\mathrm{P}<0.05$. RCC, renal cell carcinoma.

possible mechanisms of action with regard to human RCC, we focused on the Rho GTPases, which play key roles in coordinating the cellular responses required for cell migration (30). Rho pull-down assay showed that exposure of 786-0 cells to honokiol $(20 \mu \mathrm{M})$ resulted in a strong activation of RhoA (Fig. 3A). GTP $\gamma$ S, a hydrolysis-resistant GTP analog, was used as positive control (Fig. 3A). Because activity of RhoA can also be negatively regulated by its phosphorylation at Ser188 (14), the phosphorylation status of RhoA with honokiol treatment was determined in our study. Honokiol $(20 \mu \mathrm{M})$ suppressed the phosphorylation level of RhoA after 60 min without changing the level of total RhoA (Fig. 3B). Moreover, GTPase activation coincided with phosphorylation of MLC2, detected by western blot analysis with antibodies specific for phosphorylated Thr18 and Ser19 (Fig. 4). Thus, we
A

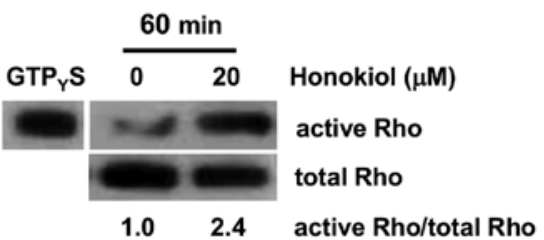

B

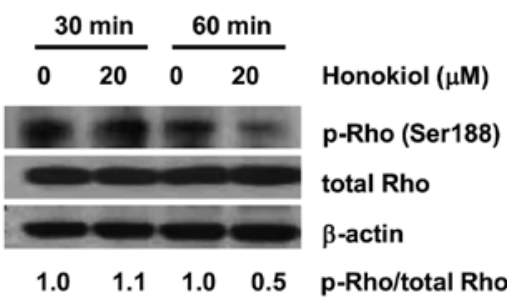

Figure 3. Honokiol stimulates RhoA activity in 786-0 cells. (A) 786-0 cells were treated with or without honokiol $(20 \mu \mathrm{M})$ for $60 \mathrm{~min}$. Rho activation assay was used to determine the level of active RhoA according to the methods described. Pull-down samples were subjected to western blot analysis using anti-RhoA antibody. (B) 786-0 cells were treated with or without honokiol $(20 \mu \mathrm{M})$ for 30 and $60 \mathrm{~min}$, respectively. Whole protein extracts isolated from cells were prepared and western blot analysis with anti-phospho-RhoA at Ser188 and anti-RhoA antibodies were performed as described in 'Materials and methods'. $\beta$-actin was used as loading control. Representative images are shown. Similar results were obtained in at least two additional experiments.

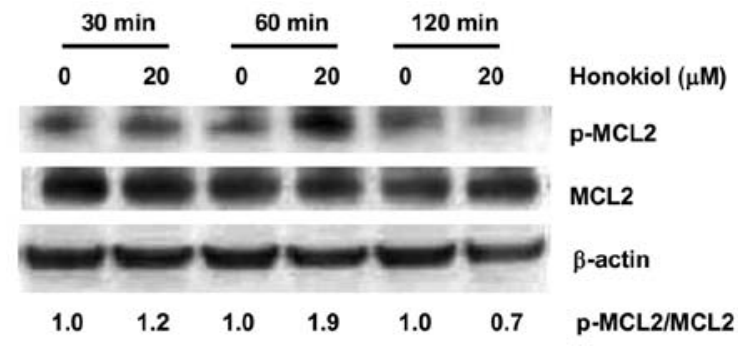

Figure 4. Honokiol increases MLC2 phosphorylation in 786-0 cells. 786-0 cells were treated with or without honokiol $(20 \mu \mathrm{M})$ for 30,60 and $120 \mathrm{~min}$, respectively. Whole protein extracts isolated from cells were prepared and western blot analysis with anti-phospho-MLC2 and anti-MLC2 antibodies was performed as described in 'Materials and methods'. $\beta$-actin was used as loading control. Representative images are shown. Similar results were obtained in at least two additional experiments. MLC, myosin light chain. 
A

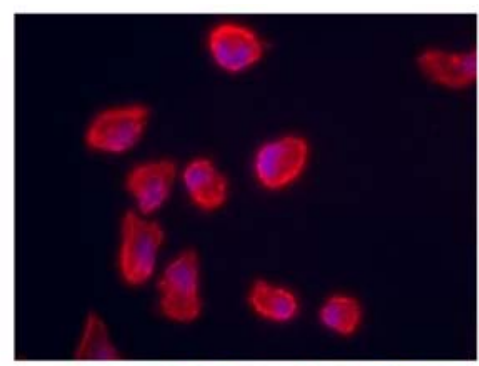

B

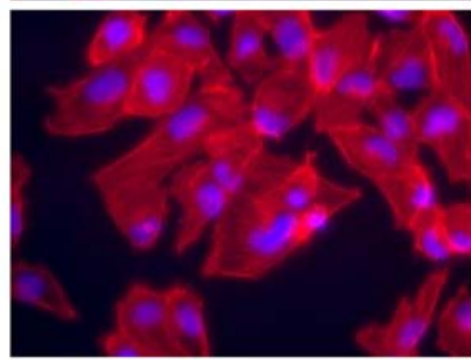

C

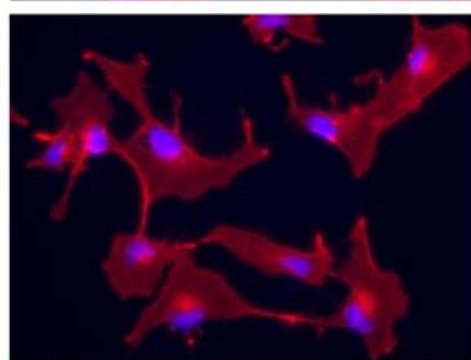

D

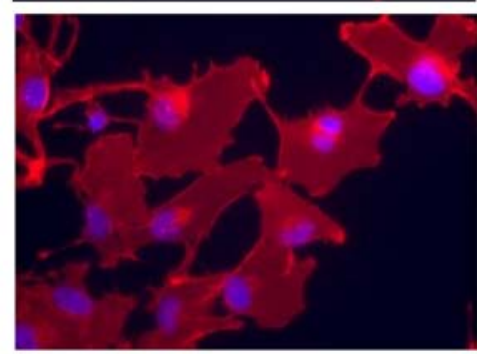

E

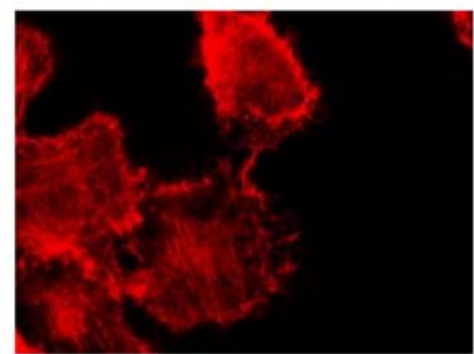

$\mathbf{F}$

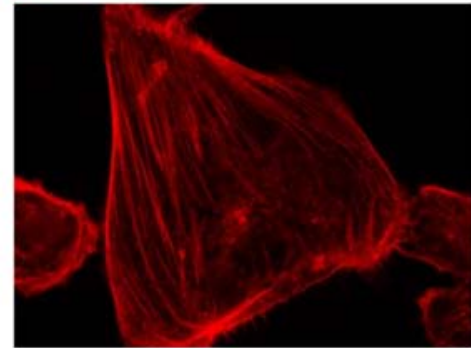

G

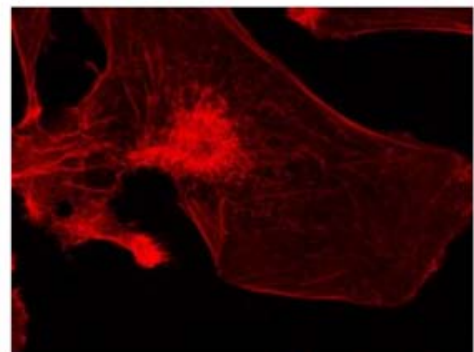

$\mathrm{H}$

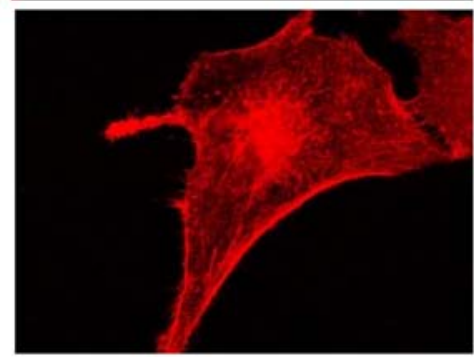

Figure 5. ROCK inhibitor attenuates contraction of actin stress fibers induced by honokiol. Cells were visualized with (A-D) fluorescence and (E-H) confocal microscopes. Treatment with honokiol $(20 \mu \mathrm{M})$ for 60 min induced excessive formation of actin fibers (rhodamine phalloidin-positive fibers) in (B and F) $786-0$ cells comparing with (A and E) the vehicle-treated control. (C and G) The effect of ROCK inhibitor Y-27623 (10 $\mu \mathrm{M})$ on honokiol-treated 786-0 cells is shown. (D and $\mathrm{H})$ The effect of Y-27623 $(10 \mu \mathrm{M})$ alone on 786-0 cells is shown. ROCK, Rho-associated protein kinase.

A

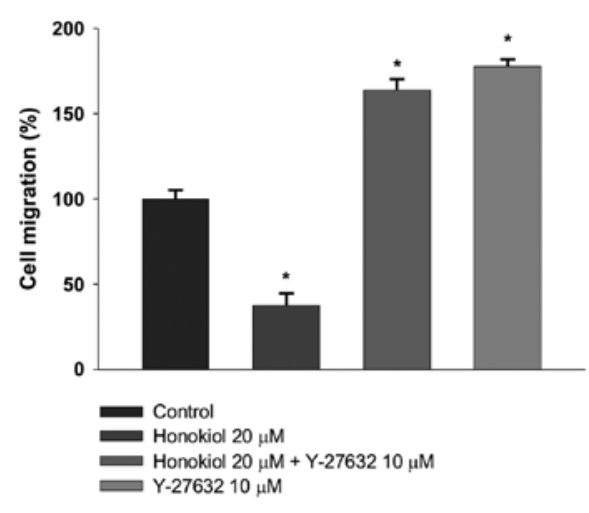

B

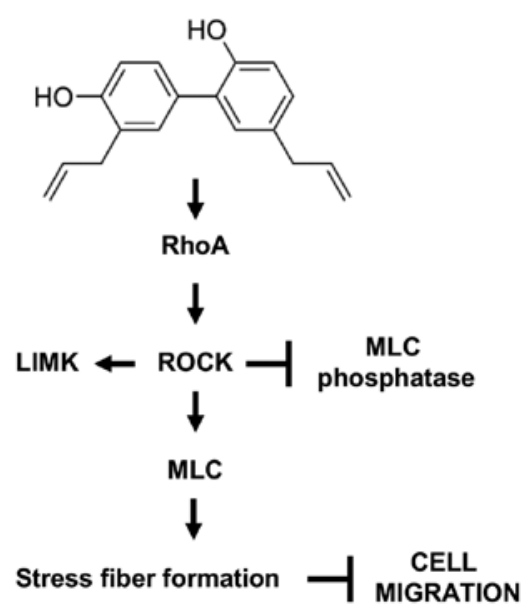

Figure 6. ROCK inhibitor abrogates honokiol-mediated inhibition of cell migration. (A) 786-0 cells were treated with or without honokiol (20 $\mu \mathrm{M})$ or honokiol $(20 \mu \mathrm{M})+$ ROCK inhibitor Y-27632 $(10 \mu \mathrm{M})$ or Y-27632 $(10 \mu \mathrm{M})$ alone and cell migration in Transwell chambers was determined as described in 'Materials and methods'. Each bar represents the mean \pm SD of one representative experiment repeated at least twice. Statistical analysis was carried out by ANOVA. "P $<0.05$. (B) Proposed mechanism of honokiol-mediated inhibition of cell migration through activation of RhoA/ROCK/MLC signaling in RCC ROCK, Rho-associated protein kinase; MLC, myosin light chain; RCC, renal cell carcinoma. 
considered that RhoA/ROCK/MLC signaling was activated by honokiol in 786- 0 cells.

ROCK inhibitor attenuates contraction of actin stress fibers induced by honokiol. Stress fibers, which look like bundles of actin filaments, are an actin-myosin-based contractile system regulated by the RhoA/ROCK/MLC signaling (31). Excessive formation of actin stress fibers (rhodamine phalloidin-positive staining of actin fibers) was identified in 786-0 cells treated with honokiol $(20 \mu \mathrm{M})$ compared with vehicle control (Fig. 5A, $\mathrm{B}, \mathrm{E}$ and $\mathrm{F})$. Interestingly, this phenomenon disappeared when cells were treated with the ROCK inhibitor Y-27632 $(10 \mu \mathrm{M})$ and honokiol (Fig. 5C and G). This inhibition can also be identified in 786- 0 cells treated with Y-27632 only (Fig. 5D and H).

ROCK inhibitor abrogates honokiol-mediated inhibition of cell migration. To determine whether the inhibition of cell migration by honokiol is mediated by the activation of RhoA/ROCK/MLC signaling in 786-0 cells, we pre-treated 786-0 cells with Y-27632 for $60 \mathrm{~min}$ and then determined cell migration with honokiol as described in 'Materials and methods'. In accordance with the change in actin stress fibers, the effect of honokiol on migration of 786-0 cells was significantly abrogated by Y-27632 (Fig. 6A). These results further proved our hypothesis that Honokiol-induced RhoA/ROCK/MLC activation plays an integral role in honokiol-mediated inhibition of migration potential in RCC (Fig. 6B).

\section{Discussion}

Cell migration is a key component of the tumor metastatic process (32). Based on a number of studies, upregulated RhoA is associated with tumor progression in different types of cancer (33-35) and RhoA activation promotes the migration of cervical, colon and hepatocellular carcinoma (36-38). However, significantly downregulated expression of RhoA was demonstrated in human conventional RCC compared to that in normal kidney tissues (17) and activated RhoA has specifically been shown to inhibit the migration of breast and prostate cancer $(39,40)$. Here, we indicated that activation of RhoA/ROCK/MLC signaling by honokiol suppresses the migration of RCC (Fig. 6B). These conflicting results reflected that the effects of altered expression of RhoA involved in cell migration were often cell type-specific (17).

Members of Rho-family GTPases, RhoA, Rac and Cdc42, control cell migration by regulating the organization of actin cytoskeleton (41). Another striking finding presented in this study is that pharmacological ROCK inhibitor Y-27632 not only rescued the effect of honokiol on migration of 786-0 cells but also tended to enhance migration. Therefore, the RhoA/ROCK/MLC signaling pathway negative regulates the migration of 786-0 cells, which is in accordance with our hypothesis. As ROCK-related signaling antagonizes the activity of Rac in osteoblasts, fibroblasts and rat basophilic leukemia cells (42-44), the involved mechanism might be through activation of Rac. Activated Rac induces the formation of actin-based sheet-like membrane projections from the cell periphery named lamellipodia (45), which plays a key role in the stimulation of cell migration (46). In accordance with this concept, Y-27632 increases lamellipodia formation in 786-0 cells (Fig. 5C and D) and further investigation is necessary to confirm the Rac stimulation.

In conclusion, this study demonstrated a novel mechanism by which honokiol inhibits migration of highly metastatic RCC, involving the activation of RhoA/ROCK/MLC signaling in vitro. Therefore, honokiol is a biologically active component with potential utility as an effective anti-migration agent in treating metastatic RCC.

\section{Acknowledgements}

We thank Mr. Kevin A. Harvey (Indiana University Health), for his technical assistance with the confocal microscope. EcoNugenics, Inc., supported this study. One of the authors, Dr I. Eliaz, acknowledges his interest as the formulator and owner of EcoNugenics, Inc.

\section{References}

1. Lee YJ, Lee YM, Lee CK, Jung JK, Han SB and Hong JT: Therapeutic applications of compounds in the Magnolia family. Pharmacol Ther 130: 157-176, 2011.

2. Kaushik G, Kwatra D, Subramaniam D, Jensen RA, Anant S and Mammen JM: Honokiol affects melanoma cell growth by targeting the AMP-activated protein kinase signaling pathway. Am J Surg 208: 995-1002, discussion 1001-1002, 2014.

3. McKeown BT and Hurta RA: Magnolol affects expression of IGF-1 and associated binding proteins in human prostate cancer cells in vitro. Anticancer Res 34: 6333-6338, 2014.

4. Zhou Y, Bi Y, Yang C, Yang J, Jiang Y, Meng F, Yu B, Khan M, Ma T and Yang H: Magnolol induces apoptosis in MCF-7 human breast cancer cells through G2/M phase arrest and caspase-independent pathway. Pharmazie 68: 755-762, 2013.

5. Tsai JR, Chong IW, Chen YH, Hwang JJ, Yin WH, Chen HL, Chou SH, Chiu CC and Liu PL: Magnolol induces apoptosis via caspase-independent pathways in non-small cell lung cancer cells. Arch Pharm Res 37: 548-557, 2014.

6. Lai YJ, Lin CI, Wang CL and Chao JI: Expression of survivin and p53 modulates honokiol-induced apoptosis in colorectal cancer cells. J Cell Biochem 115: 1888-1899, 2014.

7. Liang WZ, Chou CT, Chang HT, Cheng JS, Kuo DH, Ko KC, Chiang NN, Wu RF, Shieh P and Jan CR: The mechanism of honokiol-induced intracellular $\mathrm{Ca}(2+)$ rises and apoptosis in human glioblastoma cells. Chem Biol Interact 221: 13-23, 2014.

8. Mehlen P and Puisieux A: Metastasis: A question of life or death. Nat Rev Cancer 6: 449-458, 2006.

9. Nguyen DX and Massagué J: Genetic determinants of cancer metastasis. Nat Rev Genet 8: 341-352, 2007.

10. Monteiro $\mathbf{J}$ and Fodde R: Cancer stemness and metastasis: Therapeutic consequences and perspectives. Eur J Cancer 46: 1198-1203, 2010.

11. Deep G and Agarwal R: Antimetastatic efficacy of silibinin: Molecular mechanisms and therapeutic potential against cancer. Cancer Metastasis Rev 29: 447-463, 2010.

12. Ljungberg B, Hanbury DC, Kuczyk MA, Merseburger AS, Mulders PF, Patard JJ and Sinescu IC; European Association of Urology Guideline Group for renal cell carcinoma: Renal cell carcinoma guideline. Eur Urol 51: 1502-1510, 2007.

13. Etienne-Manneville $S$ and Hall A: Rho GTPases in cell biology. Nature 420: 629-635, 2002.

14. Ellerbroek SM, Wennerberg K and Burridge K: Serine phosphorylation negatively regulates RhoA in vivo. J Biol Chem 278: 19023-19031, 2003.

15. Pellegrin S and Mellor H: Actin stress fibres. J Cell Sci 120: 3491-3499, 2007.

16. Shoji S, Tang XY, Umemura S, Itoh J, Takekoshi S, Shima M, Usui Y, Nagata Y, Uchida T, Osamura RY, et al: Metastin inhibits migration and invasion of renal cell carcinoma with overexpression of metastin receptor. Eur Urol 55: 441-449, 2009.

17. Pu YS, Wang CW, Liu GY, Kuo YZ, Huang CY, Kang WY, Shun CT, Lin CC, Wu WJ and Hour TC: Down-regulated expression of RhoA in human conventional renal cell carcinoma. Anticancer Res 28 (4B): 2039-2043, 2008. 
18. Cheng S, Castillo V, Eliaz I and Sliva D: Honokiol suppresses metastasis of renal cell carcinoma by targeting KISS1/KISS1R signaling. Int J Oncol 46: 2293-2298, 2015.

19. Roomi MW, Ivanov V, Kalinovsky T, Niedzwiecki A and Rath M: Modulation of human renal cell carcinoma 786-0 MMP-2 and MMP-9 activity by inhibitors and inducers in vitro. Med Oncol 23: 245-250, 2006.

20. Yang F, Zhou X, Du S, Zhao Y, Ren W, Deng Q, Wang F and Yuan J: LIM and SH3 domain protein 1 (LASP-1) overexpression was associated with aggressive phenotype and poor prognosis in clear cell renal cell cancer. PLoS One 9: e100557, 2014.

21. Jiang J, Slivova V, Harvey K, Valachovicova T and Sliva D: Ganoderma lucidum suppresses growth of breast cancer cells through the inhibition of Akt/NF-kappaB signaling. Nutr Cancer 49: 209-216, 2004.

22. Sliva D, Jedinak A, Kawasaki J, Harvey K and Slivova V: Phellinus linteus suppresses growth, angiogenesis and invasive behaviour of breast cancer cells through the inhibition of AKT signalling. Br J Cancer 98: 1348-1356, 2008.

23. Lloyd FP Jr, Slivova V, Valachovicova T and Sliva D: Aspirin inhibits highly invasive prostate cancer cells. Int J Oncol 23 $1277-1283,2003$

24. Kim DW, Ko SM, Jeon YJ, Noh YW, Choi NJ, Cho SD, Moon HS, Cho YS, Shin JC, Park SM, et al: Anti-proliferative effect of honokiol in oral squamous cancer through the regulation of specificity protein 1 . Int J Oncol 43: 1103-1110, 2013.

25. Joo YN, Eun SY, Park SW, Lee JH, Chang KC and Kim HJ: Honokiol inhibits U87MG human glioblastoma cell invasion through endothelial cells by regulating membrane permeability and the epithelial-mesenchymal transition. Int J Oncol 44 187-194, 2014

26. Tian W, Deng Y, Li L, He H, Sun J and Xu D: Honokiol synergizes chemotherapy drugs in multidrug resistant breast cancer cells via enhanced apoptosis and additional programmed necrotic death. Int J Oncol 42: 721-732, 2013.

27. Hahm ER, Sakao K and Singh SV: Honokiol activates reactive oxygen species-mediated cytoprotective autophagy in human prostate cancer cells. Prostate 74: 1209-1221, 2014.

28. Chilampalli C, Zhang X, Kaushik RS, Young A, Zeman D, Hildreth MB, Fahmy H and Dwivedi C: Chemopreventive effects of combination of honokiol and magnolol with $\alpha$-santalol on skin cancer developments. Drug Discov Ther 7: 109-115, 2013.

29. Kawauchi T: Cell adhesion and its endocytic regulation in cell migration during neural development and cancer metastasis. Int J Mol Sci 13: 4564-4590, 2012.

30. Ridley AJ: Rho GTPases and cell migration. J Cell Sci 114: 2713-2722, 2001.

31. Katoh K, Kano Y, Amano M, Kaibuchi K and Fujiwara K: Stress fiber organization regulated by MLCK and Rho-kinase in cultured human fibroblasts. Am J Physiol Cell Physiol 280: C1669-C1679, 2001.

32. Navenot JM, Fujii $\mathrm{N}$ and Peiper SC: Activation of Rho and Rho-associated kinase by GPR54 and KiSS1 metastasis suppressor gene product induces changes of cell morphology and contributes to apoptosis. Mol Pharmacol 75: 1300-1306, 2009.
33. Chen S, Wang J, Gou WF, Xiu YL, Zheng HC, Zong ZH, Takano Y and Zhao Y: The involvement of RhoA and Wnt-5a in the tumorigenesis and progression of ovarian epithelial carcinoma. Int J Mol Sci 14: 24187-24199, 2013.

34. Horiuchi A, Imai T, Wang C, Ohira S, Feng Y, Nikaido T and Konishi I: Up-regulation of small GTPases, RhoA and RhoC, is associated with tumor progression in ovarian carcinoma. Lab Invest 83: 861-870, 2003.

35. Kamai T, Yamanishi T, Shirataki H, Takagi K, Asami H, Ito Y and Yoshida K: Overexpression of RhoA, Rac1, and Cdc42 GTPases is associated with progression in testicular cancer. Clin Cancer Res 10: 4799-4805, 2004.

36. Liu X, Chen D and Liu G: Overexpression of RhoA promotes the proliferation and migration of cervical cancer cells. Biosci Biotechnol Biochem 78: 1895-1901, 2014.

37. Patel M, Kawano T, Suzuki N, Hamakubo T, Karginov AV and Kozasa T: Ga13/PDZ-RhoGEF/RhoA signaling is essential for gastrin-releasing peptide receptor-mediated colon cancer cell migration. Mol Pharmacol 86: 252-262, 2014.

38. Lin L, Yang XM, Li J, Zhang YL, Qin W and Zhang ZG: Microfilament regulatory protein MENA increases activity of RhoA and promotes metastasis of hepatocellular carcinoma. Exp Cell Res 327: 113-122, 2014.

39. Takeda S, Okajima S, Miyoshi H, Yoshida K, Okamoto Y, Okada T, Amamoto T, Watanabe K, Omiecinski CJ and Aramaki H: Cannabidiolic acid, a major cannabinoid in fiber-type cannabis, is an inhibitor of MDA-MB-231 breast cancer cell migration. Toxicol Lett 214: 314-319, 2012.

40. Chen X, Corbin JM, Tipton GJ, Yang LV, Asch AS and Ruiz-Echevarría MJ: The TMEFF2 tumor suppressor modulates integrin expression, RhoA activation and migration of prostate cancer cells. Biochim Biophys Acta 1843: 1216-1224, 2014.

41. Ridley AJ, Schwartz MA, Burridge K, Firtel RA, Ginsberg MH, Borisy G, Parsons JT and Horwitz AR: Cell migration: Integrating signals from front to back. Science 302: 1704-1709, 2003.

42. Zhang X, Li C, Gao H, Nabeka H, Shimokawa T, Wakisaka H, Matsuda S and Kobayashi N: Rho kinase inhibitors stimulate the migration of human cultured osteoblastic cells by regulating actomyosin activity. Cell Mol Biol Lett 16: 279-295, 2011.

43. Tsuji T, Ishizaki T, Okamoto M, Higashida C, Kimura K, Furuyashiki T, Arakawa Y, Birge RB, Nakamoto T, Hirai H, et al: ROCK and mDial antagonize in Rho-dependent Rac activation in Swiss 3T3 fibroblasts. J Cell Biol 157: 819-830, 2002.

44. Toda M, Dawson M, Nakamura T, Munro PM, Richardson RM, Bailly M and Ono SJ: Impact of engagement of FcepsilonRI and CC chemokine receptor 1 on mast cell activation and motility. J Biol Chem 279: 48443-48448, 2004.

45. Aspenström P, Fransson A and Saras J: Rho GTPases have diverse effects on the organization of the actin filament system. Biochem J 377: 327-337, 2004.

46. Lepley D, Paik JH, Hla T and Ferrer F: The G protein-coupled receptor S1P2 regulates Rho/Rho kinase pathway to inhibit tumor cell migration. Cancer Res 65: 3788-3795, 2005. 